\title{
METODE PENYULUHAN DALAM ADOPSI INOVASI INSEMINASI BUATAN (IB) PADA USAHA PETERNAKAN SAPI DI KABUPATEN DHARMASRAYA
}

\author{
EDISET DAN JASWANDI \\ Field of Development Studies and Business Studies Ranch Ranch \\ Faculty of Animal Husbandry Universitas Andalas \\ Email : edisetjami80@gmail.com
}

\begin{abstract}
This research was conducted in the area Dharmasraya Regency, West Sumatra Province. The purpose of this study determined : a) Method of extention in innovation adoption of artificial insemination (AI) in the cattle farm in the District Dharamasraya, and b) Social and economic factors that influence adoption of innovation Artificial Insemination (AI) in the cattle farm in the District Dharmasraya. This research used survey method and approach to the analysis of secondary data. The number of samples in this study were determined by quota sampling technique by reason of homogeneous samples, the farmers were already adopting innovations and cattle ranchers IB program participants snapping Birahi Artificial Insemination (GBIB) thus took a sample of 40 people. The data collected were primary data with the help of question naires and secondary data with the literature study and related agencies. Descriptive analysis of quantitative data which was calculated using a Likert scale. The results showed that the extension method in the adoption of $I B$ in cattle breeding business in the Regency Dharmasraya been implemented, namely the extension methods home and farm visits with category, extension methods demonstrations by both categories, and the campaign extension methods with the medium category. Social and economic aspects such as business scale farmers, revenue, risk, active participation in the innovation adoption had no effect on aspects of the IB whereas age despite being influential in the adoption of innovation, but still in the category of less influential.
\end{abstract}

Keywords : extension methods, social economy, innovation adoption, Artificial Insemination (AI)

\section{PENDAHULUAN}

Pentingnya pembangunan peternakan tidak terlepas dari beberapa situasi yang ada pada saat sekarang ini, situasi itu diantaranya adalah pertambahan penduduk yang terjadi dari tahun ke tahun, korelasi dari hal ini adalah meningkatnya permintaan akan protein hewani yang berasal dari daging. Situasi berikutnya adalah regulasi pemerintah yang mana sampai saat ini masih memberlakukan kebijakan impor sapi dari negara lain, eksisting kondisi ini mengindikasikan pembangunan sub sektor peternakan belum berjalan sesuai dengan harapan dan citacita pembangunan peternakan nasional (swasembada daging).

Antisipasi dari beberapa kondisi di atas sudah dilakukan oleh stakeholder terkait,

$\begin{array}{lrrr}\text { pemerintah dalam hal ini } \begin{array}{r}\text { sudah } \\ \text { mengeluarkan }\end{array} \text { beberapa } & \text { program, }\end{array}$
diantaranya program Sarjana Membangun Desa (SMD), Sarjana Membangun Desa Wirausaha Pendamping (SMD-WP), Kredit Usaha Peternak Sapi (KUPS), Sentra Peternakan Rakyat (SPR) dan program lainnya. Realisasi dari banyak program tersebut sampai saat ini belum terwujud, buktinya swasembada daging tidak tercapai dan pemerintah masih terus memberlakukan kebijakan impor ternak sapi untuk mengantisipasi jumlah populasi sapi yang terus cendrung mengalami penurunan.

Penurunan jumlah populasi tersebut hampir terjadi sebagian besar daerah di Indonesia, salah satu daerah tersebut adalah Kabupaten Dharmasraya. Kabupaten Dharmasraya sebagai bagian dari daerah transmigrasi sudah menjalankan usaha peternakan sapi sejak dimulainya program 
transmigrasi oleh pemerintah pusat yaitu tahun 1979. Peserta program transmigrasi ini diberi bantuan sapi untuk setiap kepala keluarganya melalui program Banpres (Bantuan Presiden) sehingga sampai saat ini sebagian besar masyarakat yang ada di daerah ini masih memelihara ternak sapi secara intensif. Pemeliharaan dengan sistem intensif ini seyogyanya mampu meningkatkan jumlah populasi ternak sapi di Kabupaten Dharmasraya, namun secara statistik jumlah populasi tersebut cendrung mengalami penurunan, dimana berdasarkan data tahun 2012, jumlah populasi ternak sapi adalah 31.449 ekor dengan klasifikasi 7.920 ekor sapi jantan dan 23.529 ekor sapi betina, pada tahun 2013 jumlah populasi mengalami penurunan sebanyak 4.690 ekor dimana jumlah populasi ternak pada tahun 2013 sebanyak 26.759 ekor, dengan jumlah 5.808 ekor sapi jantan dan 20.951 ekor sapi meskipun pada tahun 2014 kembali meningkat menjadi 39.512 ekor hal ini disebabkan oleh jumlah pemotongan pada tahun yang sama jauh turun dari tahun tahun sebelumnya, yaitu hanya 2.842 ekor (Dinas Perternakan dan Perikanan Kabupaten Dharmasraya, 2015).

Statistik data di atas menggambarkan kebijakan pemerintahan secara makro dan sistem pemeliharaan yang baik belum tentu mampu mendukung tercapainya jumlah populasi yang sesuai dengan kebutuhan, untuk itu perlu didukung oleh program pemerintah yang bersifat persuasif dan intensif seperti program penyuluhan dalam membantu penerapan inovasi dibidang peternakan. Inovasi bidang peternakan itu diantaranya adalah inovasi bioteknologi reproduksi, yaitu inovasi Inseminasi Buatan (IB). Inovasi Inseminasi Buatan (IB) merupakan bagian dari bioteknologi reproduksi, dimana melalui teknologi ini perkawinan ternak tidak lagi dilakukan secara alami menggunakan pejantan, melainkan mengambil semen dari pejantan yang dimasukan ke dalam rahim sapi betina yang dilakukan oleh inseminator, hal ini dilakukan dengan tujuan untuk memperbaiki mutu genetik dan produktivitas ternak sapi.

Bioteknologi reproduksi Inseminasi Buatan (IB) akan diadopsi secara efektif oleh peternak jika dilakukan melalui program penyuluhan, untuk itu berhasil atau tidak berhasilnya kegiatan penyuluhan ditentukan oleh beberapa unsur, diantaranya adalah unsur penyuluhnya, unsur inovasi (pesan), unsur penerima (peternak sasaran) maupun unsur media dan metoda penyuluhannya. Metoda penyuluhan merupakan salah satu unsur penyuluhan yang dapat mempengaruhi tingkat keberhasilan adopsi inovasi, dimana metode penyuluhan seperti kunjungan rumah/usaha tani, demontrasi /percontohan dan kampanye merupakan jenis metode penyuluhan yang relevan dengan kondisi peternak dan mudah untuk diterapkan. Kesesuaian antara metode dengan kondisi peternak sasaran akan dapat mempercepat terjadinya proses adopsi inovasi, yang pada akhirnya berimplikasi positif terhadap usaha peternakan yang dilakukan.

Keberhasilan program penyuluhan dalam adopsi inovasi dipengaruhi juga oleh kondisi sosial ekonomi peternak sasaran, dimana kondisi sosial ekonomi tersebut dapat berupa luas skala usaha, tingkat pendapatan, keberanian mengambil resiko, umur, tingkat partisipasi serta aktivitas mencari ide baru. Kondisi sosial ekonomi peternak akan mempengaruhi proses dan kecepatan peternak sasaran dalam mengadopsi inovasi dan secara tidak langsung juga akan memberi kemudahan pada penyuluh dalam penerapan inovasi yang ditawarkannya. 


\section{Perumusan Masalah}

Bagaimana metode penyuluhan yang diterapkan dan pengaruh faktor sosial ekonomi peternak dalam adopsi inovasi Inseminasi Buatan (IB) pada usaha peternakan sapi di Kabupaten Dharmasraya.

\section{Tujuan Penelitian}

Mengetahui metode penyuluhan yang diterapkan dan pengaruh faktor sosial ekonomi peternak dalam adopsi inovasi Inseminasi Buatan (IB) pada usaha peternakan sapi di Kabupaten Dharmasraya.

\section{METODE PENELITIAN}

\section{Lokasi Penelitian}

Penelitian ini dilaksanakan di Kabupaten Dharmasraya, yaitu di daerah transmigrasi Sitiung yang merupakan daerah percontohan program Gertak Birahi Inseminasi Buatan (GBIB) yang di tetapkan oleh Pemerintahan Daerah Kabupaten Dharmasraya.

\section{Pengumpulan Data}

Penelitian ini merupakan jenis penelitian survei yaitu pengamatan atau penyelidikan yang kritis untuk mendapatkan keterangan yang baik terhadap suatu persoalan tertentu di dalam daerah atau lokasi tertentu (Wirartha, 2006)

Data yang dikumpulkan pada penelitian ini adalah data primer dan data sekunder sesuai dengan kebutuhan penelitian. Data primer diperoleh dari hasil wawancara langsung dengan peternak yang ada di lokasi penelitian serta dengan mewawancarai secara mendalam (Indepth Interview), stakeholder terkait yang dianggap mengetahui persoalan yang diteliti. Data primer digunakan untuk mengidentifikasi metode penyuluhan dalam adopsi inovasi Inseminasi Buatan (IB). Sementara itu data sekunder diperoleh dari literatur, Badan Pusat Statistik (BPS), Dinas Peternakan, Badan Penyuluhan Pertanian (BPP) dan instansi terkait lainnya.

\section{Populasi dan Sampel Penelitian}

Populasi adalah seluruh peternak sapi yang sudah mengadopsi inovasi Inseminasi Buatan (IB) karena populasi relatif homogen maka populasi peternak sapi yang sudah mengadopsi inovasi IB tersebut diquotakan (quota sampling) menjadi 40 orang untuk dijadikan sampel dengan pertimbangan sudah memiliki anak sapi hasil IB.

\section{Metode Pengolahan dan Analisis Data}

Untuk menjawab kedua tujuan penelitian ini yaitu 1) metode penyuluhan, 2) faktor sosial ekonomi dilakukan analisis secara deskriptif kuantitatif. Untuk jenis analisis ini dihitung menggunakan skala likert. Skala likert digunakan untuk mengukur sikap, pendapat dan persepsi seseorang untuk kelompok tentang fenomena sosial (Sugiyono, 2014). Melalui skala likert, variabel akan diukur dan dijabarkan melalui indikator variabel. Kemudian indikator tersebut dijadikan sebagai titik tolak untuk menyusun item-item instrument yang dapat berupa pernyataan atau pertanyaan (Sugiyono, 2014). Untuk analisis kuantitatif maka jawaban diberi skor sebagai berikut :

1) Setuju (ST) : Skor 3

2) Ragu-Ragu (RR) : Skor 2

3) Tidak Setuju (TS) : Skor 1

Data aspek yang diperoleh, dikumpulkan dalam bentuk tabel, kemudian dihitung berdasarkan skor masing-masing sesuai dengan "Pedoman Identifikasi Faktor Penentu Teknis Peternakan Ditjen Peternakan 1992". Selanjutnya nilai skor yang diperoleh dibandingkan dengan 
kategori yang telah ditetapkan oleh Ditjen Peternakan (1992) yaitu:
a) Kategori baik/berpengaruh, persentase yang diperoleh $81-100 \%$
b) kategori sedang/berpengaruh sedang, persentase yang diperoleh $60-80 \%$
c) kategori kurang/berpengaruh kurang, persentase yang diperoleh $<60 \%$

\section{HASIL DAN PEMBAHASAN}

\section{Metode Penyuluhan dalam Adopsi Inovasi Bioteknologi Reproduksi Inseminasi Buatan}

\section{Metode Kunjungan Rumah dan Usaha Tani}

Hasil penelitian merujuk dari Tabel 1 memperlihatkan metode penyuluhan kunjungan rumah dan usaha tani sudah dilaksanakan dalam adopsi inovasi Inseminasi Buatan (IB) di Kabupaten Dharmasraya, dimana pada metode ini pelaksanaanya berada pada kategori sedang dan apabila dilihat dari persentase rataan skor sudah hampir berada pada kategori baik, karena untuk kategori baik persentase rataan skor minimal adalah $81 \%$. Kategori sedang tidak terlepas dari masih kurang tersedianya sumber daya penyuluh, baik yang berasal dari dinas terkait seperti Badan Penyuluh Pertanian (BPP) maupun yang berasal dari instansi swasta. Menurut Undang Undang Nomor 16 tahun 2006 dalam (Mardikanto, 2010) ragam penyuluh/fasilitator dikelompokan atas tiga bagian, yaitu penyuluh pemerintah, penyuluh swasta dan penyuluh swadaya. Penyebab lain belum terlaksananya metode kunjungan rumah dan usaha tani secara optimal adalah masih tumpang tindihnya peran yang dilakukan oleh para penyuluh yang ada, dimana pada daerah penelitian di samping berperan sebagai penyuluh peternakan, para penyuluh juga berperan sebagai penyuluh pertanian, hal ini ditenggarai akan berimplikasi kurang baik dengan ketersediaan tenaga, waktu bagi penyuluh dan ditambah lagi dengan keberadaan usaha ternak dan peternak yang akan disuluh tersebar di lokasi yang berjauhan.

Tabel 1. Jawaban responden tentang metode penyuluhan dalam adopsi inovasi Inseminasi Buatan (IB)

\begin{tabular}{lllcccc}
\hline No & Metode & Indikator & Jumlah (n) & Jumlah Skor & Rataan Skor (\%) & Kategori \\
\hline \multirow{2}{*}{1} & \multirow{2}{*}{ Kunjungan Rumah } & Setuju & 32,0 & 96 & 80,0 & \\
& dan Usaha Tani & Ragu Ragu & 8,0 & 16 & 20,0 & Sedang \\
& & Tidak Setuju & 0,0 & 0 & 0,0 & \\
\multirow{2}{*}{2} & \multirow{2}{*}{ Demonstrasi } & Setuju & 36,0 & 108 & 90,0 & \\
& & Ragu Ragu & 4,0 & 8 & 10,0 & Baik \\
& & Tidak Setuju & 0,0 & 0 & 0,0 & \\
\multirow{2}{*}{3} & Kampanye & Setuju & 29,0 & 87 & 72,5 & \multirow{2}{*}{ Sedang } \\
& & Ragu Ragu & 8,0 & 16 & 20,0 & \\
\hline
\end{tabular}

Sumber : Hasil Penelitian tahun 2016

Konsekuensi yang akan terjadi dengan keterbatasan waktu dan tenaga tersebut adalah penyuluh secara tidak langsung tidak akan mampu mendatangi setiap peternak maupun usaha peternakan yang ada, karena dengan metode kunjungan rumah dan usaha ternak ini akan mengharuskan setiap penyuluh datang kepada setiap peternak untuk memberikan penyuluhan, tentu ini membutuhkan waktu 
dan tenaga yang besar. Anwar dkk (2009) berpendapat metode penyuluhan dan kunjungan usaha ternak memiliki beberapa hambatan seperti : memerlukan waktu dan tenaga yang lebih banyak jika dibandingkan metode lain, jumlah petani peternak yang dapat dikunjungi terbatas, kunjungan yang sering dilakukan kepada seorang petani akan menimbulkan prasangka pada petanipetani lainnya.

\section{Metode Demonstrasi}

Tabel 1 memperlihatkan metode demonstrasi sudah terlaksana dengan baik, dimana persentase skor rataan hasil penelitian adalah 90\%. Angka persentase ini membuktikan pelaksanaan metode demonstrasi dalam adopsi inovasi bioteknologi reproduksi Inseminasi Buatan (IB) di Kabupaten Dharmasraya berada pada kategori baik. Terlaksananya dengan baik metode ini disebabkan oleh penyuluh dalam melaksanakan kegiatan penyuluhan langsung mendemontrasikan kegiatan inseminasi pada saat melakukan penyuluhan, yang mana pada kegiatan penyuluhan tersebut diikutsertakan juga tenaga inseminator.

Efektifnya metode ini juga didukung oleh proses penyuluhan yang dilakukan, dimana pada pelaksanaan kegiatan penyuluhan dilakukan pada suatu kelompok peternak yang memilki populasi induk produktif yang banyak, sehinga peluang untuk melaksanakan demonstrasi cukub besar, dimana setelah penyuluh memberikan materi tentang Inseminasi Buatan (IB) dapat langsung dilakukan IB oleh tenaga Inseminator pada ternak sapi yang yang sedang birahi yang dimiliki oleh kelompok yang disuluh, setelah itu penyuluh rutin melakukan kunjungan ke kelompok tersebut untuk penanganan pasca penerapan inovasi IB sampai ternak yang di IB bunting dan melahirkan. Anwar dkk
(2009) menjelaskan demonstrasi merupakan salah satu metode penyuluhan pertanian yang dilaksanakan untuk menunjukkan suatu cara atau membuktikan suatu hasil usahatani yang lebih baik, demonstrasi dikatakan sebagai suatu percontohan.

Berhasilnya pelaksanaan metode ini juga didukung oleh jenis inovasi yang diterapkan, karena pada prinsipnya peternak sebagai adopter pasti mempertimbangkan segala konsekuensi dari adopsi inovasi tersebut, sehingga secara umum peternak akan cendrung menerapkan suatu inovasi dengan biaya murah dan tingkat keberhasilan yang tinggi, hal ini tidak terlepas dari kondisi perekonomian peternak pada umumnya memiliki penghasilan rendah. Mardikanto (2010) menjelaskan dalam adopsi suatu inovasi para adopter akan mempertimbangkan sifat-sifat instrinsik dari inovasi, seperti informasi ilmiah yang melekat, nilai-nilai atau keunggulankeunggulan, tingkat kerumitan inovasi, mudah tidaknya dikomunikasikan inovasi, mudah tidaknya inovasi tersebut dicobakan mudah tidaknya inovasi tersebut diamati.

Berbeda dengan metode ceramah atau pidato, dimana dalam demonstrasi tidak diperlukan adanya saling mempercayai yang tinggi antara peternak dengan penyuluh karena melalui demonstrasi peternak dapat melihat sendiri segala sesuatu dengan jelas tentang inovasi yang akan diadopsi. Van Den Ben dalam terjemahan Herdiasti (1996) mengungkapkan bahwa demonstrasi dapat mendorong petani mencoba sendiri inovasi baru.

\section{Metode Kampanye}

Penelitian memperlihatkan hasil yang hampir sama untuk setiap metode penyuluhan yang diterapkan dalam adopsi inovasi bioteknologi reproduksi Inseminasi 
Buatan (IB), termasuk penerapan metode kampanye dalam proses adopsi inovasi tersebut, dimana berdasarkan Tabel 1 persentase rataan skornya adalah $72,5 \%$, yang menandakan metode kampanye ini berada pada kategori sedang, belum optimalnya penerapan metode kampanye ini disebabkan oleh sulitnya mengumpulkan peternak atau pemilik usaha peternakan sapi untuk dapat berpartisipasi pada saat penyuluh melaksanakan kegitan penyuluhan, hal itu disebabkan oleh para peternak tersebut memiliki aktivitas, kesibukan dan pekerjaan yang berbeda. Anwar dk (2009) menyatakan tempat dan waktu pelaksanaan penyuluhan, sebaiknya juga harus disesuaikan dengan kesepakatan masyarakat tentang waktu dan tempat yang biasa mereka gunakan untuk keperluankeperluan serupa.

Kelemahan lain yang menyebabkan belum terlaksananya metode kampanye ini secara baik adalah dana, biasanya untuk memobilisasi sasaran yang banyak diperlukan juga dana dan tenaga yang cukup sehingga untuk hal hal yang seperti ini diperlukan dukungan dari berbagai pihak. Dana, tenaga dan dukungan tersebut harus diatur sedemikian rupa dan bisanya memerlukan waktu yang lama juga sehingga hal-hal yang seperti ini menimbulkan keengganan dari penyuluh untuk melakukan metode kampanye ini, ditambahkan Anwar dkk (2009) bahwa untuk melaksanakan penyuluhan dengan metode kampanye memerlukan persiapan yang cermat dan terencana, memerlukan dana dan tenaga yang cukup besar, memerlukan kerjasama yang baik dengan berbagai pihak.

Status Sosial Ekonomi Peternak Sapi Pesisir yang Berpengaruh terhadap Adopsi Inovasi Inseminasi Buatan (IB)

\section{Pengaruh Skala Usaha}

Skala usaha kurang berpengaruh dalam adopsi inovasi Inseminasi Buatan (IB) bagi peternak di Kabupaten Dharmasraya, dimana persentase rataan skor hasil penelitian hanya sebesar 45\%, itu menandakan skala usaha hanya berada pada kategori yang kurang berpengaruh. Kurang berpengaruhnya ukuran skala usaha dalam adopsi inovasi IB disebabkan karena inovasi IB tersebut hanya dapat diterapkan pada ternak sapi jenis betina produktif, dan kecendrungannya usaha peternakan sapi rakyat skala kepemilikannya hanya $\pm 1-5$ ekor, dengan jumlah populasi yang seperti biasanya juga terdapat ternak sapi betina didalamnya. Ediset dan Jaswandi (2014) menyatakan jumlah ternak sapi yang paling banyak dipelihara oleh peternak yang ada di daerah transmigrasi Kabupaten Dharmasraya adalah 1-5 ekor yang menandakan usaha peternakan sapi didaerah ini masih kategori skala rumah tangga. Hasil dari pengaruh skala usaha ini mencerminkan untuk mengadopsi inovasi Inseminasi Buatan (IB) tidak mesti harus memiliki jumlah sapi yang banyak, tetapi dengan memelihara ternak sapi betina 1-2 ekor saja inovasi IB sudah dapat di adopsi oleh peternak. Anwar dkk (2009) menyatakan salah satu syarat suatu pesan/inovasi dapat diterima oleh sasaran adalah suatu inovasi tersebut dapat disesuaikan dengan keberadaan sumber daya dari masyarakat sasaran.

\section{Pengaruh Pendapatan}

Mencermat dari Tabel 2 memperlihatkan pendapatan juga kurang berpengaruh terhadap peternak dalam mengadopsi inovasi Inseminasi Buatan (IB), dimana persentase rataan skor pendapatan hanya $42,5 \%$ yang membuktikan aspek pendapatan hanya berada pada kategori kurang berpengaruh, karena berdasarkan 
rujukan yang dipakai dalam penelitian persentase rataan skor terendah untuk kategori berpengaruh adalah 81\% (Ditjen Peternakan, 1992). Pendapatan yang kurang berpengaruh dalam adopsi inovasi IB tersebut sejalan dengan program pemerintahan daerah setempat, dimana pada tahun 2015 pemerintah daerah khususnya Dinas Peternakan dan Perikanan Kabupaten Dharmasraya melaksanakan program Gertak Birahi Inseminasi Buatan (GBIB), dimana melalui program ini para peternak yang melakukan usaha peternakan sapi merasa terbantu, karena melalui program tersebut dinas membebaskan biaya bagi peternak yang mau mengadopsi Inseminasi Buatan dan anak hasil IB akan diperlombakan dan bagi yang juara akan medapatkan reward. Hal lain yang dipedomani oleh peternak adalah biaya pelaksanaan sekali IB yang masih terbilang murah yaitu Rp. 40.000/IB, biaya ini menurut peternak logis dibandingkan hasil yang akan diperoleh setelah anak hasil IB lahir. Kondisi usaha yang dirasakan oleh peternak ini sejalan dengan pendapat Anwar dkk (2009) yang menyatakan sasaran akan cepat melakukan adopsi inovasi apabila inovasi yang akan diterapkan tidak memerlukan korbanan yang memberatkan serta memberikan harapan peluang keberhasilan yang tinggi dan tingkat manfaat yang merangsang.

\section{Pengaruh Resiko yang Dihadapi}

Besar kecilnya resiko yang dihadapi oleh peternak kurang berpengaruh dalam adopsi inovasi Inseminasi Buatan (IB), hal ini terlihat dari hasil penelitian berdasarkan Tabel di atas, dimana persentase rataan skor dari resiko adalah 50\%, artinya adalah sebesar apapun resiko yang akan ditimbulkan akibat melakukan adopsi inovasi IB, tetap kurang berpengaruh terhadap kemauan peternak untuk mengadopsinya di masa yang akan datang. Hal ini disebabkan karena peternak percaya dan paham bahwa dalam menerapkan sesuatu yang baru tidak akan terlepas dari resiko, baik itu resiko materi maupun resiko waktu. Kurang berpengaruhnya resiko yang dihadapi dalam proses adopsi inovasi juga disebabkan karena sebelum mengadopsi inovasi IB, peternak/usaha peternakan sudah memperoleh informasi dan pengetahuan dari penyuluh tentang hal hal yang berkaitan dengan inovasi IB tersebut, baik manfaat, cara, tujuan serta resiko kegagalan yang bakal diterima seandainya inovasi IB itu belum berhasil, sehingga dengan pahamnya peternak calon adopter dengan resiko yang akan diterima akan mengurangi ketakutan peternak untuk mencoba mengadopsinya. Soedarmanto (2003) mengedepankan bahwa seorang penyuluh harus memahami informasi terkait dengan inovasi yang disampaikan dalam upaya untuk mengurangi resiko kegagalan sekecil mungkin dan di samping itu penyuluh dituntut mahir secara fisik.

\section{Pengaruh Umur}

Hasil penelitian menunjukan umur berpengaruh sedang terhadap proses adopsi inovasi Inseminasi Buatan (IB) di daerah Kabupaten Dharmasraya, hal ini terlihat dari persentase rataan skor umur hanya $50 \%$, yang menandakan dalam adopsi inovasi, umur berada pada kategori berpengaruh sedang. Penyebab umur berpengaruh sedang dalam adopsi inovasi IB adalah karena sebagian besar peternak yang ada di daerah ini berada pada usia produktif. Hasil penelitian Ediset dan Jaswandi (2014) adalah 73,33\% peternak di Kabupaten Dharmasraya berada pada usia produktif yaitu berusia 18-55 tahun. Hal ini sesuai dengan ketetapan BPS Sumatera Barat (2006), bahwa umur 15-64 tahun adalah usia produktif dalam berusaha. 
Umur produktif ini akan berperan besar terhadap usaha yang dilakukan oleh peternak, terutama dalam hal pengambilan keputusan. Menurut Mardikanto (2009) dalam Sidadora (2010) umur seseorang merupakan salah satu faktor yang mempengaruhi persepsinya dalam pembuatan keputusan untuk menerima segala sesuatu yang baru.

\section{Pengaruh Tingkat Partisipasi}

Tingkat partisipasi peternak dalam kelompok juga kurang berpengaruh terhadap adopsi inovasi Inseminasi Buatan di daerah penelitian, dimana persentase rataan skor pengaruh tingkat partisipasi tersebut hanya sebesar $20 \%$, persentase rataan skor ini menggambarkan adopsi inovasi IB dapat saja dilakukan oleh setiap peternak/usaha peternakan meskipun peternak tersebut tidak berada atau tidak terikat dalam suatu kelompok peternak. Peternak dalam menerapkan suatu inovasi lebih cendrung mencari informasi sendiri, baik kesesama peternak, berita di media maupun dari sumber lain. Fakta ini memperjelaskan peternak sapi di daerah ini tidak memiliki ketergantungan pada peternak tertentu maupun pada kelompok tertentu, meskipun seyogyarnya seorang peternak tersebut lebih beruntung berada dalam suatu kelompok dibandingkan dengan berada di luar kelompok, karena dengan keberadaanya dalam kelompok akan mudah dan cepat memperoleh informasi yang dibutuhkan dari sesama anggota tapi kelemahannya belum tentu lebih inovatif. Lionberger dalam Anwar dkk (2009) mengemukakan peternak yang yang suka bergabung dengan orang berada di luar sistem sosialnya sendiri umumnya lebih inovatif dibandingkan dengan mereka yang hanya melakukan kontak pribadi dengan warga masyarakat setempat.

\section{Pengaruh Tingkat Keaktifan}

Hasil penelitian dilihat dari aspek tingkat keaktifan mecari informasi sama dengan hasil pada aspek lainnya, yaitu tingkat keaktifan kurang berpengaruh bagi peternak dalam proses adopsi inovasi Inseminasi Buatan (IB), secara persentase rataan skornya adalah $32,5 \%$, hal ini jelas bahwa tingkat keaktifan berada pada kategori kurang berpengaruh. Kurang berpengaruhnya tingkat keaktifan ini disebabkan oleh peternak di daerah ini sering didatangi oleh penyuluh dan kemudian dalam adopsi inovasi IB selalu memakai jasa petugas inseminator setelah mendapatkan penyuluhan tersebut. Inseminator akan bersedia untuk datang melakukan IB pada ternak sapi peternak di saat sapi birahi meskipun hanya di hubungi melalui telepon saja, itu artinya inseminator selalu ada kapan saja dibutuhkan. Anwar dkk (2009) mempertegas inovasi akan terasa mudah untuk diadopsi apabila apa yang ditawarkan sesuai dengan kebutuhan sasaran dan disampaikan pada saat, sedang dan atau segera akan dibutuhkan.

\section{KESIMPULAN}

Metode penyuluhan kunjungan rumah usaha tani, demonstrasi dan kampanye sudah dilaksanakan dalam adopsi Inovasi Inseminasi Buatan (IB) di Kabupaten Dharmasraya namun demikian hanya metode demonstrasi yang sudah terlaksana dengan baik, sedangkan status sosial ekonomi peternak sapi yang ada di daerah ini kurang berpengaruh dalam adopsi inovasi Inseminasi Buatan (IB), baik dilihat dari skala usaha, pendapatan, resiko yang dihadapi, umur, tingkat partisipasi, serta keaktifan diluar kelompok. 
Tabel 2. Jawaban responden tentang pengaruh status sosial ekonomi peternak terhadap adopsi inovasi

\begin{tabular}{|c|c|c|c|c|c|c|}
\hline No & $\begin{array}{c}\text { Status Sosial } \\
\text { Ekonomi }\end{array}$ & Indikator & Jumlah n & Jumlah Skor & $\begin{array}{c}\text { Rataan } \\
\text { Skor (\%) }\end{array}$ & Kategori \\
\hline \multirow{3}{*}{1} & \multirow{3}{*}{ Skala Usaha } & Setuju & 18,0 & 54,0 & 45,0 & \\
\hline & & Ragu Ragu & 15,0 & 30,0 & 37,5 & Kurang \\
\hline & & Tidak Setuju & 7,0 & 7,0 & 17,5 & Berpengaruh \\
\hline \multirow{3}{*}{2} & \multirow{3}{*}{ Pendapatan } & Setuju & 17,0 & 51 & 42,5 & \multirow{3}{*}{$\begin{array}{c}\text { Kurang } \\
\text { Berpengaruh }\end{array}$} \\
\hline & & Ragu Ragu & 17,0 & 34,0 & 42,5 & \\
\hline & & Tidak Setuju & 6,0 & 6,0 & 15,0 & \\
\hline \multirow{3}{*}{3} & \multirow{3}{*}{ Resiko } & Setuju & 20,0 & 60,0 & 50,0 & \multirow{3}{*}{$\begin{array}{c}\text { Kurang } \\
\text { Berpengaruh }\end{array}$} \\
\hline & & Ragu Ragu & 16,0 & 32,0 & 40,0 & \\
\hline & & Tidak Setuju & 4,0 & 4,0 & 10,0 & \\
\hline \multirow{3}{*}{4} & \multirow{3}{*}{ Umur } & Setuju & 29,0 & 87 & 72,5 & \multirow{3}{*}{$\begin{array}{l}\text { Berpengaruh } \\
\text { Sedang }\end{array}$} \\
\hline & & Ragu Ragu & 7,0 & 14,0 & 17,5 & \\
\hline & & Tidak Setuju & 4,0 & 4,0 & 10,0 & \\
\hline \multirow{3}{*}{5} & \multirow{3}{*}{$\begin{array}{l}\text { Tingkat } \\
\text { Partisipasi }\end{array}$} & Setuju & 8,0 & 24,0 & 20,0 & \multirow{3}{*}{$\begin{array}{c}\text { Kurang } \\
\text { Berpengaruh }\end{array}$} \\
\hline & & Ragu Ragu & 20,0 & 40,0 & 50,0 & \\
\hline & & Tidak Setuju & 12,0 & 12,0 & 30,0 & \\
\hline \multirow{3}{*}{6} & \multirow{3}{*}{ Keaktifan } & Setuju & 13,0 & 39,0 & 32,5 & \multirow{3}{*}{$\begin{array}{c}\text { Kurang } \\
\text { Berpengaruh }\end{array}$} \\
\hline & & Ragu Ragu & 16,0 & 32,0 & 40,0 & \\
\hline & & Tidak Setuju & 11,0 & 11,0 & 27,5 & \\
\hline
\end{tabular}

Sumber : Hasil Penelitian Tahun 2016

\section{UCAPAN TERIMA KASIH}

Terima kasih kami sampaikan kepada Lembaga Penelitian dan Pengabdian Masyarakat (LPPM) Universitas Andalas yang telah memberi kepercayaan dan bantuan pendanaan untuk melaksanakan kegiatan penelitian ini.

\section{DAFTAR PUSTAKA}

Anwar, S., F. Madariza dan A. Anas. 2009. Ilmu Penyuluhan Pertanian. Universitas Andalas, Padang.

Dinas Peternakan dan Perikanan Kabupaten Dharmasraya tahun 2015. Data Base Populasi Ternak Besar Kabupaten Dharmasraya.
Ditjen Peternakan. 1992. Pedoman Identifikasi Faktor Penentu Teknis Peternakan. Proyek Peningkatan Produksi Peternakan. Diklat Peternakan. Jakarta.

Ediset dan Jaswandi. 2014. Karakteristik Peternak dan Aspek teknis Usaha Peternakan Sapi Potong di Daerah Transmigrasi Kabupaten Dharmasraya. Jurnal Agrotripical. $4(1)$.

Hawkins, H.S. dan A.W. Van Den Ban. 1996. Penyuluhan Pertanian, Diterjemahkan oleh Agnes Dwina Herdiasti. Kanisius, Jakarta.

Mardikanto, T .2006. Komunikasi Pembangunan. Sebelas Maret University Press. Surakarta.

2010. Komunikasi Pembangunan. Acuan Bagi Akademisi, Praktisi dan Peminat Komunikasi Pembangunan. UNS Press. Surakarta. 
Soedarmanto, 2003.Penyuluhan dan Komunikasi Pertanian.Teori dan Penerapannya. Buku Referensi. Program Studi Penyuluhan dan Komunikasi Pertanian. Universitas Brawijaya. Malang.

Sidadora, Y. 2010. Persepsi dan Adopsi Peternak Sapi Potong. Skripsi Fakultas Peternakan Universitas Andalas. Padang.
Sugiyono. 2014. Metode Penelitian Kuantitatif Kualitatif dan R\&D. Alfabeta. Bandung.

Wirartha, I. M. 2006. Metodologi Penelitian Sosial Ekonomi. CV. Andi Offset. Yogyakarta 